しめられているためと考えられる。

4) $I_{T} / I_{L}$ が最適值より小さいと, 溶鋼へッドを支え るアーク压力は先行電桠アークが受持古, 逆に $I_{T} / I_{L}$ が 大きい上後行アーク压力のみで溶鋼へッドを支えるよう になる.

とれらの实効的なアーク圧力が溶鋼の全重力ヘッドよ り大となったとき，アンダーカットが発生する。

5) $I_{T} / I_{L}$ が最適值のときでは, 丽電極アークの溶鏰 重力ヘッドに作用する帮效的なアーク压力は等しくかつ 最低值をとる。

\section{謝 辞}

本研究の遂行にあたり，御指導いただいた大阪大学の 西口公之教授，黄地润義助教授，および佐滕邦彦教授に 厚く感等の意を表します。

\section{参考 文 献}

1）西口，黄地，高；莒速不安定ビード形成現象に関与る研究，溶接つ 一ク物理研究委員会資料，74-252（1974）

2) B.E. Paton, S.L. Mandel'berg, B.G. Sidorenko; Certain Special Features of the Formation of Welds
Made at High Speeds, Avt. Svarka, 8 (1971), 1-6

3）石䗁；高速溶接時のビード形状の生成機橉，溶接 只会資料，72-197 (1972)

4）山内，商；大電流 TIG 溶接法，溶接フーク物理研究委員会貲料。 78-369 (1978)

5）小倉，二瓶，芦田，小園；2䉓医スイッチング TIG 溶接法による 高速溶接，溶按アーク物理研究委員会资料，81-459 (1981)

6）赤零, 浮辺, 坪井; 大電流サブマージフークに 関与る二, 三の特 性，溶接 7一ク物理研究委員会資料，78-383 (1978)

7) C. Duren, R. Felleisen, G. Hieber ; Four Beats Three in Submerged.Arc Welding, Weld. \& Met. Fab., 49-4 (1981), 205-210

8）中根，吉田，関野，㙁川；サブマージフーク路接に拈ける容接鋼の

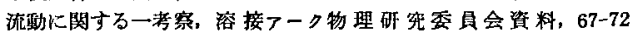
(1967)

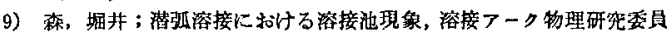
会资料, 70-105 (1970)

10) B. J. Bradstreet; Effect of Surface Tension and Metal Flow on Weld Bead Formation, Weld. J., 47-7 (1968), 314S-322S

11) P. Eichhorn, A. Engel; Mass Transter in the Welding Pool, IIW Doc. SG212-201-70 (1970)

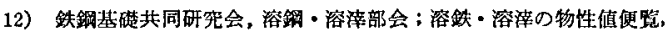
日本鉄嵞協会，(1972），6-9

13）奥田，平社，㓋谷；サブマージフーク溶接のビード外観に及活すフ

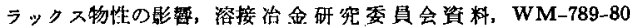
(1980)

\title{
構造用鋼溶接継手の溶込み不良の超音波による 検出と疲労試験による品質評価*
}

\author{
稲垣 道夫**，岡田 明**，小林志希男**，木村 勝美**，福原 熙明*** \\ 松本庄次郎***, 青术 孝夫***, 中野 恵司***，兼古 光行***
}

\section{Quality Evaluation of Welded Joints for Structural Steels with the Ultrasonic Detection of Lack of Penetration and Fatigue Test*}

by Michio Inagaki**, Akira Okada**, Shikio Kobayashi**, Katsuyoshi Kimura** Hiroaki Fukuhara**, Shojiro Matsumoto**, Takao Aoki**, Keishi Nakano**, and Mitsuyuki Kaneko**

For purpose to obtain the fundamental data of securing the reliability of welded joints, the establishment of welding control technique to make weld defects of arc welded joints in the natural condition, the design and trial making of ultrasonic point focussed probe in order to detect quantitatively planar defects and their application were carried out. And also, effects of the lack of penetration with one side welding of SM50B steels on the fatigue test results of welded joints were investigated. The main results are as follows;

(1) Relation between the lack of penetration and welding condition in gas metal arc (GMA) welding were made clear.

(2) The point focusing angle probe using spherical tansduser in ultrasonic detecting method was applied

\footnotetext{
*原稿受付 昭和56年11月11日（昭和55年度秋季全国大会にて筧表）

**正 具 金属材料技術研究所 Member, National Researh

Institute for Metals

*** 金属材料技術研究所, National Research Institute for Metals
} 
to the measurement of the size of lack of penetration. In case that the root face of butt welded joint was gas cut, the detecting accuracy was about $\pm 0.5 \mathrm{~mm}$. However, in case that there were blow-holes or some weld defects on the way of passing of ultrasonic beam or near the root, the size of planar defect was often mistaken. And also, in case that the root face was closely attached by welding, the detection of lack of penetration was often difficult.

(3) The uniaxial stress fatigue strength of arc welded joints for SM50B steels which have the lack of penetration of about $2 \sim 4 \mathrm{~mm}$ in depth, without reinforcement and finished surface, was extremely lower than that of base metal and welded joints which have full penetration, without reinforcement and finished surface. And the fatigue strength of arc welded joints with reinforcement showed the intermediate values between that of base meial or welded joints which have without reinforcement and finished surface and that of welded joint which have the lack of penetration of about $2 \sim 4 \mathrm{~mm}$ in depth, lowered fairly in comparison with that of base metal. These test results were discussed with non-linear fracture mechanics, consequently, the fatigue limits of welded joints are evaluated with effective notch depth as a whole.

\section{1. 緒言}

この破究は，溶接槛造物の品質保証の一環として，製 作時の品質管理，製作後の受入れ検查及び供用期間中の 保安管理のため, 溶接継手の信頼性の基碟資料を得るこ とを目的とし，Fig. 1・示すように金材技研内の研究体 徏のもとに遂行されているあのである。

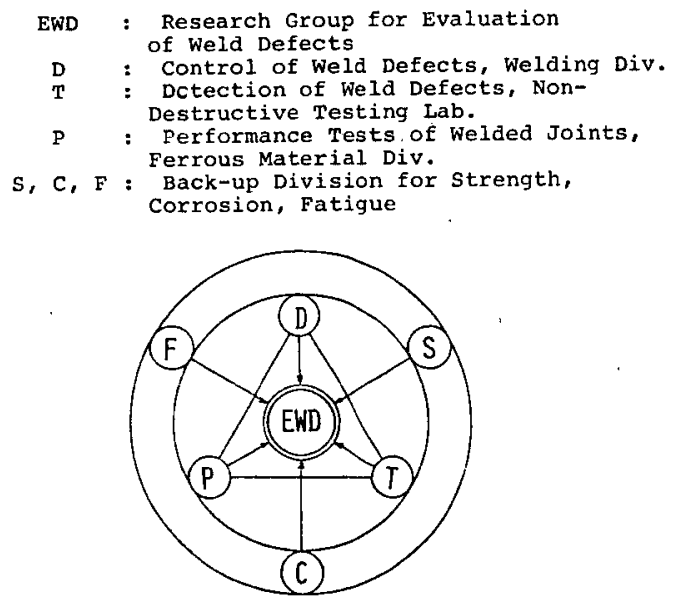

Fig. 1 System research for evaluation of weld defects in National Research Institute for Metals (NRIM)

この赤告では，主としてガスメタルアーク（GMA）溶 接法を用い，ブローホールやピットを防止し，溶込み形 状や余盛北状を制御する方法の確立，溶込み不良などの 寸法を定量的に测定するための点集束斜的探能子の設計 試作とそれを用いた超音波試験法の確立，ならびに上記 成果に基ついて製作された所定の片側溶込み不良を含む SM $50 \mathrm{~B}$ 鋼（板厚 $20 \mathrm{~mm}$ ) の滘接継手の点集束斜解挆触 子に上る溶込み不良哚さの定晴的测定とそれら継手の大 気中痏労試験の結果について述べる。疫労試験の結 果 は，母材，余盛削除完全溶込み溶接継手，及び余盛付溶
接継手の結果と比較した。また，疫学破断後の破面観察 を行い，溶接継手の溶込多不良への点集束斜的橴蟲子の 適用性について検討するととむに，疲労試験の䋹㷊に刘 して若干の破壊力学的解析を行った。

\section{2. 溶接欠陷亡溶接施工条件亡の関係}

ガスメタルアーク（GMA）溶接法を用い，溶込み不 良,ブローホール，ピットなどと䍇接諸条件との関係を 圾験検討し，これらの欠陷を制御する方法を確立した。

\section{1 溶接両端近傍におけるアークの不安定}

GMA 溶接法で開先内を母材の始端吕ら終端まで溶摈 する場合，目材の端部での磁束密度分有の变化で発生す るアークブローは，数多くの溶揬実験を行った結果，母 材端面から約 $7.5 \mathrm{~cm}$ の籍囲内であった。遖流定電圧特 性の電源では，アークブローが発生すると，溶揬電流は 減少傾向になるかあるいは短絡を繰返し夜動する。との ため溶接雨端近傍ては溶込みが減少したり変陲する.

溶接試験片の製作においては，浴接開始端乙終端部に 母材之同じ材質のタブ板（tab）を溶接し，アークブロー の発生を軽減するととむに，始端と終端の $5 \mathrm{~cm}$ の溶 接長部分は使用しないことにした。

\section{2 溶滴移行現象とブローホール, ピットの生成}

GMA 溶接における溶榈移行形態は溶接条件によって 異なり,アークの安定性と局部的な溶込みの变動, ス パッタの発生及びブローホールやピットの生成》などに 大きく影響する。Fig. 2 は，シールドガスとして $A_{\mathrm{r}} 25$ $1 / \mathrm{min}+\mathrm{CO}_{2} 5 \mathrm{l} / \mathrm{min}$ の中に $1 \mathrm{l} / \mathrm{min}$ の窒素ガスを添扣し た場合の各程溶接条件に上る溶滴移行形態领域上ピット 及びブローホールの生成との相関関係を示したもので， ピット及びブローホールはストリーミング移行及び短絡 移行ではほとんど生成しなかったが，グロビュール移 行，プロジェクト移行及びグロビュール移行と短絡移行 の中间領域で多く生成した。

したがって, 通常の GMA 溶接において, シールド 


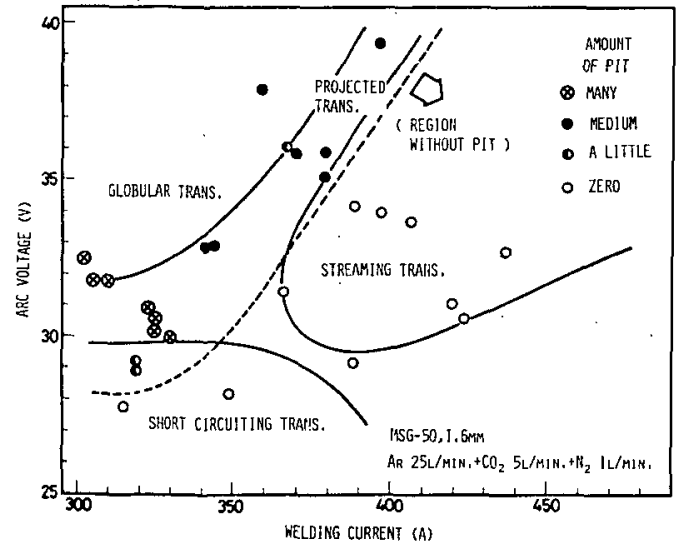

Fig. 2 Correlation between field of droplet transfer type and occurence of pit in shielding gas with $\mathrm{N}_{2}$ gas

ガス中に空気が風などによって巻込まれたり，ルート ギャップから空気が侵入した場合，それが溶接金属内に 败収される度合は，ストリーミング移行か短絡移行の領 域が最も少ないと推定される。

\section{3 溶接条件とビード形状}

懕さ $20 \mathrm{~mm}$ の平板上にビードを琶き溶按したときの 溶込み及び熱影響部（HAZ）の形状を調べた，その絬 果, 溶接条件に上る HAZ の形状变化は溶入み形状变化と ほほ刘応するが, 澹込みと HAZ の寸法の差は, 深さ方 向よりあ幅方向の方が大きくなるという特徽があった。

次に，余盛形状はアーク電死によって大きく変化する ことがわかった。Fig. 3 にその例を示す。

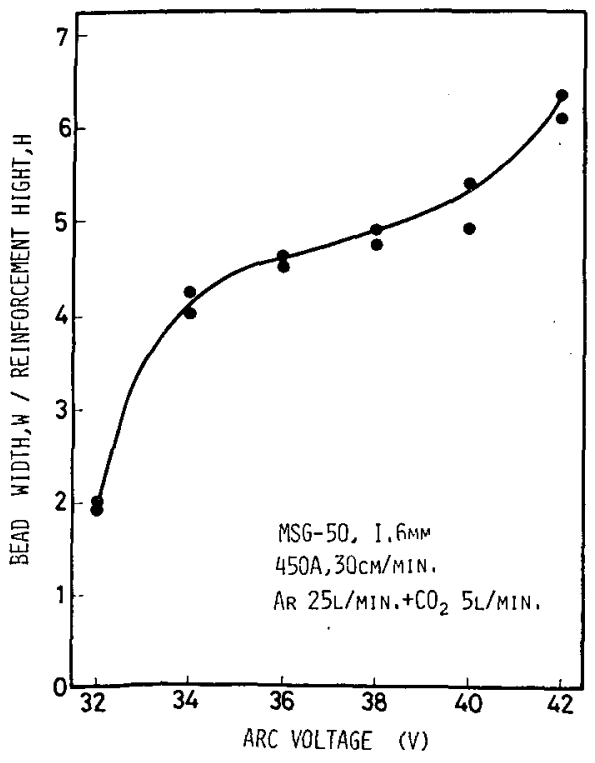

Fig. 3' Effect of arc voltage on shape of reinforcement
以上のような成果をあとに, 非破罗試騟による検出用 及び波労試験用などの溶込み不良を含む多数の溶接継手 を製作した。

\section{3. 超音波探傷用点集束斜角探触子による欠 宿寸法の测定}

溶入み不良の定量的な寸法测定のために，端部ピーク エコ一法に適した点集束斜角探触子を開発し，その適用 を榆討した。

\section{1. 点集束斜角探触子の試作}

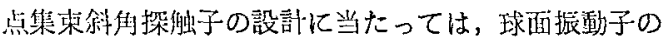
音朝上の音正 ${ }^{2)}$, 焦点付近の細いビームの存在範因 ${ }^{3)}$, 屈 折による細いビームの長さの短維けとつき検討し，点集 束斜任探触子の音場の計算を行った，その結果に基づい

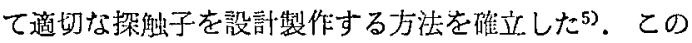
ような力法によって，䧓波数 $2 \sim 7 \mathrm{MHz}$ ，振動子の直径 $10 \sim 48 \mathrm{~mm}$, 曲率半偟 $30 \sim 200 \mathrm{~mm}$ の十数個の点集束科 们探触子の設部と試作を行った。

試作した探触子の基本特性，すなわち程々の深さ位䈯 におりる超音波ビームの集束状沉及び穴王上昇状沉の測 定には，主として Fig. 4 に示すような愦穴試験片を用 いた．乙れを水平方向移動台上に载せ，探触子と横穴の 相刘估置精度を $0.02 \mathrm{~mm}$ 程度に保持できるようにし， 探触子の基本特性を前後走查により测定した。なお，使 用超音波探儌器结三䔖電機製 FD $210 \mathrm{~S}$ である。

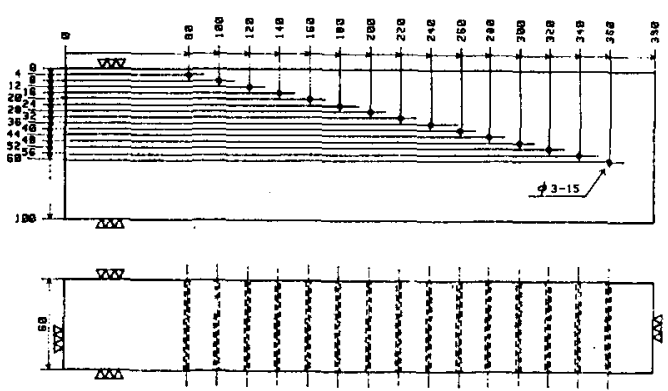

Fig. 4 Side drilled hole test block

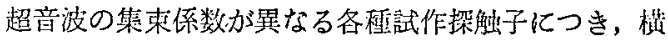
穴試験片の各橫穴によるエコー高さ分布を記録し検討し た. その結果，集束係数加比較的小さい梊触子の場合， 穴の梁さが $4 \mathrm{~mm}$ 程度のときのみ凹凸のある前後走查 グラフとなり，近距離干涉帯の影響が現われるが，それ より樑い位置の穴の前後走查グラフは単純な山形すなわ

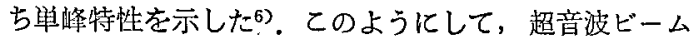
が細く絞られ，探傷に適した集束領域を検討した:

次に，Fig. 5 に示す人工溝付試験片を作製し，横穴試 


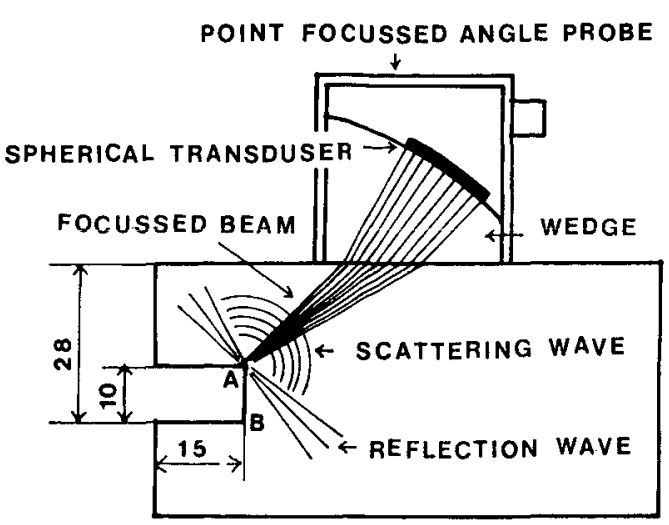

Fig. 5 Performance of point focussed probe using slit defect test block

験片による場合と同様に, 人工溝付試験片の前後走查を 行い，エコー高さが極大となる位䇴の探触子の移動距離 と㖤折角と加ら人工瑇の高さを測定した.

との人工瑇付試験片につき，点集束斜的探触子及び通 常の斜角探触子を用いて求めた人工溝の前後走查グラフ の例を Fig. 6 に示す. 点集束挆触子では前後走查グラフ の形が鋭くなり，エコーピークの位䈯も明確である。こ の実験加ら，点集束涂㑇探触子による人工欠宿の菖さ測 定誤差は約 $0.25 \mathrm{~mm}$ 以下と判断される.なお，こてで 使用した探触子の屈折的はいずれも $45^{\circ}$ であるので，ピ 一ク間距離から直ちに人工欠陷の酮さが読みとれる ${ }^{6}$.

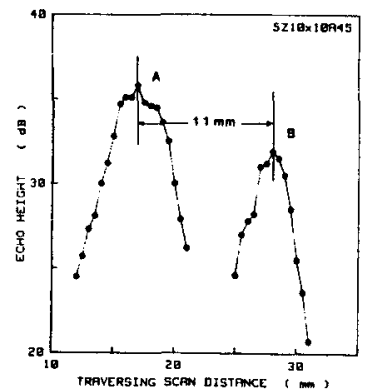

(.) NORMRL AMGLE PROBE

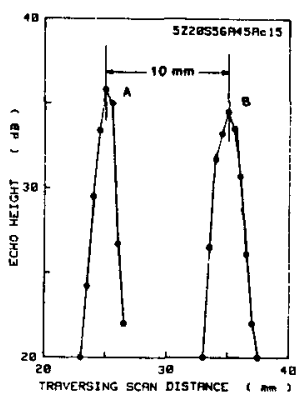

(b) POINT FOCUSSED ANGLE PROBE
Fig. 6 Measurement of height of defect by traversing scan graph

\section{2 溶接継手の溶込み不良の寸法測定}

欠陥位置の精密測定には，その欠宿深さ位置を想定し 前出 Fig. 4 の横穴試験片を用い想定された欠陥深さ位 置に近い2つの横穴について行う「ビーム路程差法」が 良いとの結論が別に得られている7). そてで，てのビー 么路程差法により溶接継手の溶込み不良の寸法測定方法 を実験検討した。
片側溶込み不良の寸法測定を点集束斜的探触子を用い て行う埥合，Fig. 7 に示すように，溶込み不良の反対側 加ら测る方法 (A法) と溶込み不良側から测る方法 (B )とがある。ここで用いた溶接繼手試験片の板厚は $18 \mathrm{~mm}$ で, 溶込み不良の梁さが $2 \sim 6 \mathrm{~mm}$ 程度である.

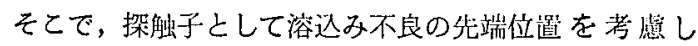
て，焦点位置が適切な点啭束斜㑬探倔子を選んで用い た. 2 個の溶込み不良試験片についての啭験結果の例を Fig. 8 に示す.

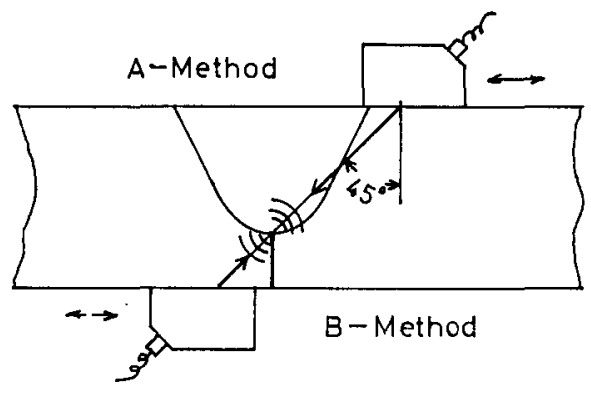

Fig. 7 Measuring methods of the size of lack of penetration

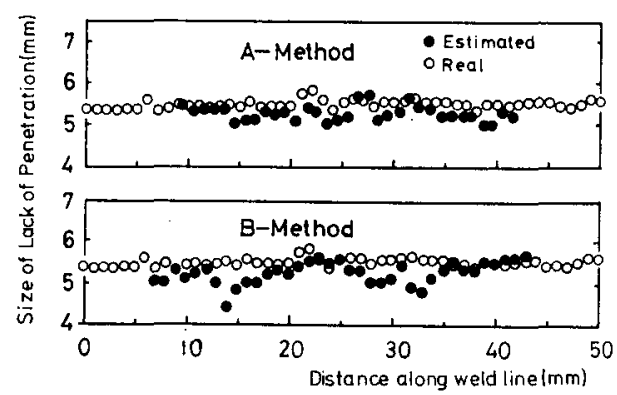

(a) Test piece Al

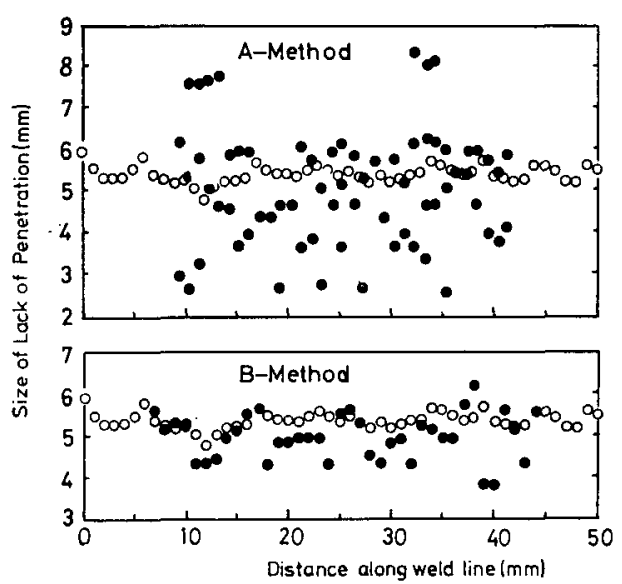

(b) Test piece A20

Fig. 8 Measured resuts of the size of lack of penetration 
試験片 A1 については, 超音波による推定值（黒丸） と疲労破断後の破面上で工具顕微鏡によって測定した結 果（白丸）とは, 数点の例外を除けばかなりよく一致 し, 超音波による测定誤差は $\pm 0.5 \mathrm{~mm}$ 程度と判断さ れる.しかし, 試験片 A 20 については超音波による推 定值は大きくばらついている，A法では超音波ビームが 溶接金属中を通過するため, Fig. 9 の疲労破面写真に見 られるような途中のブローホールなどを検出し, これを 溶迀不良の先端と䛊認するととがある. GMA 溶接に よる溶込み不良の先端には往々にしてブローホールが存 在することがあり, このような場合には溶込み不良の先 端位置が正確に求められなくなる。試験片 A 20 のA法 の場合はまさにこれに該当しており，B法の方が適して いると判断される。しかし，B法では溶込み不良の寸法 が $2.5 \mathrm{~mm}$ 以下になると, Fig. 10 に示すように溶込み 不良の表面開口部のエコーと溶込み不良の先端のエコー とが分離しなくなり，测定が不可能となる.

また，A法であ B法であ溶込み不良を著しく浅く誤認 している場合があるが，乙の原因として，溶接線方向に

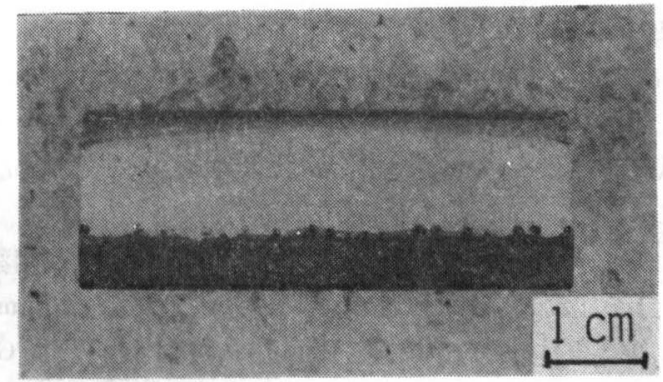

Fig. 9 Macrograph showing blow holes at the bottom of penetration

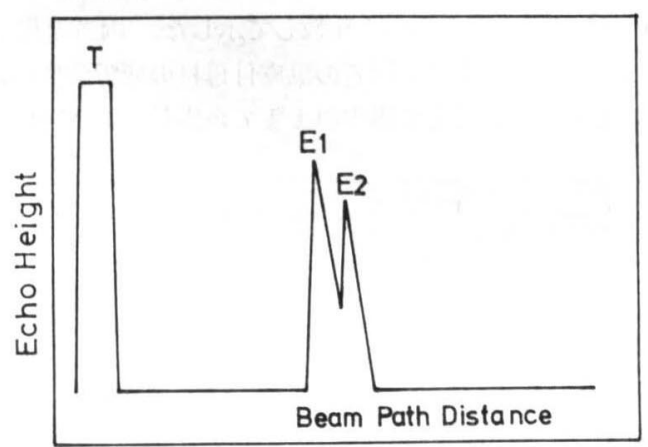

Fig. 10 Measuring limit of B-method in very shallow lack of penetration $\mathrm{T}$ : Transmitted pulse, $\mathrm{E}_{1}$ : Echo from the corners consisted of the surface and the lack of penetration, $\mathrm{E}_{2}$ : Echo from the tip of lack of penetration
平行な機械仕上げによるルート面上の凹凸からのエコー を検出していると推定される，通常の溶接継手では， ルート面はガス切断のままの場合が多いので, 機械仕上 面の方向性の問題はないと判断される.

次に突合せ継手において両側から GMA 溶接を行い, 溶込み深さを制御して内部溶込み不良に含む試験片を製 作し, 内部溶込み不良の検出特性を検討した.

継手のルート面を溶接線方向と平行にシェーパ仕上げ した試験片では，機械仕上げ面からのエコーが大きく， 上・下端のエコーの判別が困難であったので, ルート面 を平面研削盤で仕上げ，かつ，ところどてろ $0.02 \sim 0.1$ $\mathrm{mm}$ だけ深く研削し, 意識的にルート間隔を与えて溶接 継手試験片を製作した。溶接入熱量が過少で，ルート面 の両端に若干の融合不良が発生した場合には, 上・下端 のエコーは明確に検出されたが，ルート間隔が 0 で， GMA 溶接の入熱量が通常 $(15 \mathrm{~kJ} / \mathrm{cm})$ か多少大きい $(35 \mathrm{~kJ} / \mathrm{cm})$ の場合には, 溶接金属の収縮のためルート 面が強く密着され, 超音波ピームが透過してしまい, 溶 込み不良が検出されない場合が生じるととが示された. 現実にルート面を研削仕上げするととはないであろう が，かなり平滑に機械仕上げされる場合があるようであ り, その場合にルート面が溶接により密着されると, 超 音波探傷による溶込み不良の検出が不可能になることが 予想される。

\section{SM 50 B 鋼溶接継手の疲労試験による溶 込み不良の品質評価}

SM 50 B 鋼の片側溶込み不良を含む溶接継手 試験片 の大気中疲労試験を行い, 母材, 余盛削除完全溶込み溶 接継手, 及び余盛付溶接継手の結果と比較し, 若干の破 壊力学的検討を加えた.

\section{1 実験方法}

供試材として JIS SM 50 B 銓板 $(20 \mathrm{mmt})$ で, Table 1 に示すような市販の標準的な化学成分と強度を有する

Table 1 Chemical composition and mechanical property of SM50B steel, $20 \mathrm{~mm}$ in thickness

(a) Chemical composition of steel used (wt\%)

\begin{tabular}{c|c|c|c|c}
\hline$C$ & $S i$ & $M n$ & $P$ & $S$ \\
\hline 0.14 & 0.34 & 1.32 & 0.018 & 0.007 \\
\hline
\end{tabular}

(b) Mechanical property of steel used

\begin{tabular}{|c|c|c|c|}
\hline $\begin{array}{l}\text { Yield } \\
(\mathrm{kg} / \mathrm{mm}\end{array}$ & $\begin{array}{l}\text { gith } \\
\left./ \mathrm{mm}^{2}\right\}\end{array}$ & $\begin{array}{c}\text { Tensile strength } \\
\left(\mathrm{kg} / \mathrm{mm}^{2}\right)\left\{\mathrm{N} / \mathrm{mm}^{2}\right\}\end{array}$ & $\begin{array}{c}\text { Elongation } \\
(\%)\end{array}$ \\
\hline 36.2 & $\{355\}$ & $\{500\}$ & 30 \\
\hline
\end{tabular}


あのを選定し使用した．既に 2 章で述べたような成果を あとに, Fig. 11 に示す GMA 溶接施工法と溶接条件で, 深さ 2 4 mm の片側溶込み不良を含む溶接継手試験片 を多数製作した。 また，溶込み不良の寸法（深さ）は, 点集束斜角探触子を用いて測定した。
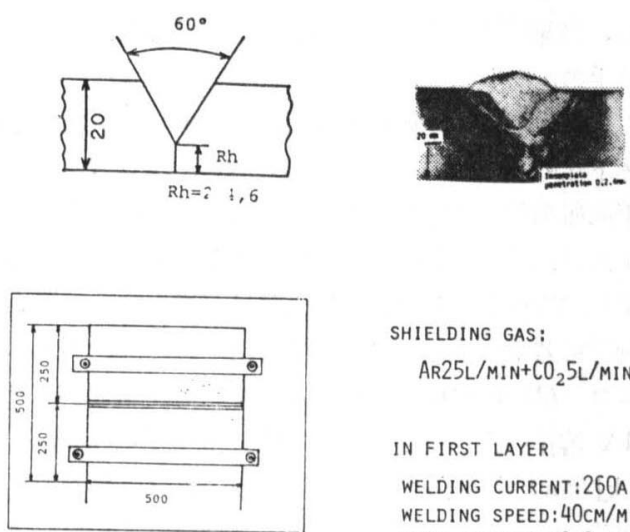

SHIELDING GAS: $A R 25 \mathrm{~L} / \mathrm{MIN}+\mathrm{CO}_{2} 5 \mathrm{~L} / \mathrm{MIN}$

IN FIRST LAYER WELDING CURRENT:260A WELDING SPEED: $40 \mathrm{cM} / \mathrm{MIN}$ WIRE DIAMETER: I,2MM

OVER SECOND LAYER WELDING CURRENT: 390A

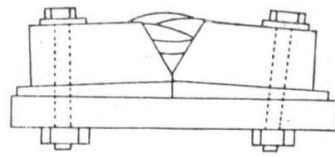
WELDING SPEED:30 CM/MIN WIRE DIAMETER: I.6MM

Fig. 11 Manufacturing of test material of GMA welded joint with lack of penetration

疫労試験には， \pm 50 ton 油圧サーボ疲労試験機を用い 軸荷重制御の片振り引張疲労試験方法 ${ }^{8)}$ により, 応力比 $\mathrm{R}$ (下限応力 $\sigma_{\min } /$ 上限応力 $\sigma_{\max }$ ) $=0$, 繰返し速度 5 $\mathrm{Hz}$ で行った．母材及び溶接継手の疲労試験片の平行部 幅はいずれも $50 \mathrm{~mm}$ とした，母材試験については，黒 皮付きと表面研削仕上げの両者とし, 黒皮付きの場合の 板厚は $20 \mathrm{~mm}$, 表面研削仕上げの場合の板厚は $18 \mathrm{~mm}$ とした，溶接継手試験片については，溶込み不良のない 完全溶込みのもの, 深さ $2 \sim 4 \mathrm{~mm}$ 程度の片側溶入み不 良を含むむのとし，余盛りはいずれあ削除して表面研削 仕上げを行い，板厚は $18 \mathrm{~mm}$ とした.

\section{2 実験結果と考察}

SM 50 B 鋼母材及び溶接継手の疲労試験結果を一括 して Fig. 12 に示す. この結果によれば, 表面研削仕上 げを行った母材と黒皮付きの母材の疲労強度は近似して いるが, 表面研削仕上げを行った母材の疲労強度の方が わずかに高かった，溶込み不良がなく完全溶込みで余盛 りを削除して表面研削仕上げを行った溶接継手の疲労強 度は，黒皮付きの母材のそれとほとんど同じ值を示し

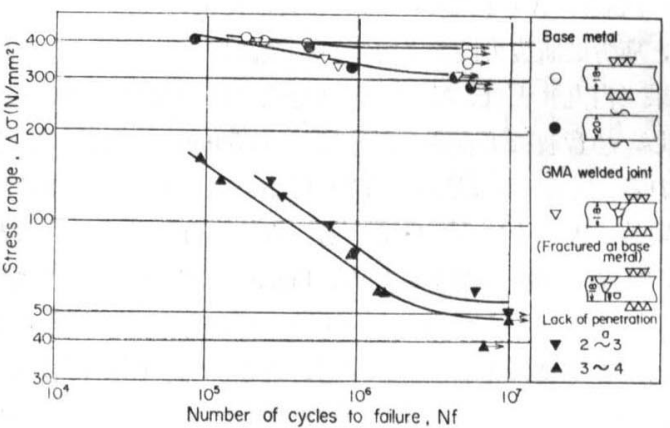

Fig. 12 Effect of discontinuities on uniaxial stress fatigue test results for JIS SM50B steel, $20 \mathrm{~mm}$ in thickness, stress ratio $\mathrm{R}=0$

た.したがって溶接による材質的不連続が瘦労強度に及 ぼす影響はわずかしか認められなかった。しかし，潹さ 2 4 mm の片側溶込み不良を含み，余盛りを削除して 表面研削仕上げを行った溶接継手の瘦労強度は，母材及 び溶込み不良なし（完全溶込み）で余盛削除仕上げの溶 接継手のそれに比べて著しく低下した。なお，溶込み不 良の深さは，溶接試験片の製作上縓密に制御するととが 困難で，2 4 $\mathrm{mm}$ の範囲にばらつき，かつ瘦労試験の測 定点む少ないが, 溶込み不良の樑さが $2 \sim 3 \mathrm{~mm}$ の継手 試験片と, 3 4 $\mathrm{mm}$ の継手試験片とでは, 疲労限度 $\Delta \sigma_{e}$ に約 $10 \mathrm{~N} / \mathrm{mm}^{2}$ 程度の差異が認められるようである.

一方, 金材研 (NRIM) において作成されている溶接 継手の疲れデータシートの中から, SM 50 B 鋼 $(20 \mathrm{~mm}$ t）の黒皮付母材及び余盛付被覆アーク (MAC) 及び $\mathrm{G}$

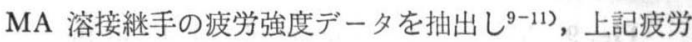
試験結果と比較したあのを Fig. 13 に示す. 疲れデータ シートにおいて使用した SM 50 B 鋼の化学成分は, Fig 13 の上部に今回のあのと比較して示した。両者の化学 成分は類似しており, 両者の黒皮付母材の疲労強度はほ ぼ等しかった。そして黒皮のままで余盛付きの MAC及

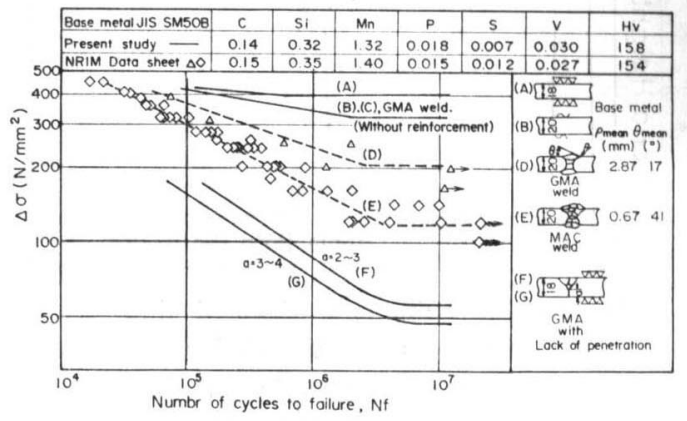

Fig. 13 Comparison of fatigue lives between NRIM data sheet and present study 
び GMA 溶接継手の疲労強度は，母材のそれ之溶込み不 良を會む溶接継手のそれの中间の值を示し，母材の疲労 強度に比べてかなり低下した。

そとで，Fig.13 の結果について若干の破壊力学的検 討を行った，宇佐美らは，溶接継手に含まれる微小き裂 について非線形破壊力学的榆討を行い, き裂先端での繰

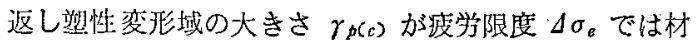
料定数 $\gamma_{p(c) e}$ に等しい之設定して, 次の関係式を導い $た^{12)}$.

$$
\begin{aligned}
& \gamma_{p(c)}=\gamma_{p(c) c} . \\
& \gamma_{p(c)}=a_{c}\left(\sec \frac{\pi \Delta \sigma_{c}}{4 \sigma_{y c}}-1\right), R \geq 0 \\
& \gamma_{p(c)}=a_{c}\left\{\sec \frac{\pi}{2\left(2 \sigma_{y c} / \sigma_{\max }+R\right.}-1\right\}, \mathrm{R} \leqq 0
\end{aligned}
$$

ここで， $\sigma_{y c}$ は材料の繰返し降伏強さで，粼的引張降 代強さの 0.7 倍として ${ }^{12)}$. 当供試銓 SM 50 B 銅の静的 引張降伏強さは $355 \mathrm{~N} / \mathrm{mm}^{2}$ であるので $\sigma_{y c}$ は $249 \mathrm{~N} /$ $\mathrm{mm}^{2}$ となる．また $a_{e}$ は然限板中の有効き裂潹さ（き裂 半長)で次式で示される13).

$$
a_{e}=\frac{1}{\pi}\left(\frac{K}{\sigma_{0}}\right)^{2}
$$

ここで $K$ は応力拡大係数， $\sigma_{0}$ は公称冲力である.

また，小䙺模降伙条件下では次の関係が成立つ12)。

$$
\gamma_{p(c) e}=\frac{\pi}{32}\left(\frac{\Delta K_{\mathrm{th}}}{\sigma_{y c}}\right)^{2}
$$

ここで $\Delta K_{\text {th }}$ は波学き裂進限限界值であり，次式で示 される13).

$$
\Delta K_{\mathrm{th}}=\Delta \sigma_{e} \sqrt{\pi a} \cdot f\left(\frac{a}{t}\right)
$$

ここで $a$ はき裂㳭さ, $t$ は帊厚, $f\left(a^{\prime} t\right)$ は $a / t$ の関 数で次式を採用した ${ }^{13)}$.

$$
\begin{aligned}
& f\left(\frac{a}{t}\right)=1.12-0.231\left(\frac{a}{t}\right)+10.55\left(\frac{a}{t}\right)^{2} \\
& -21.72\left(\frac{a}{t}\right)^{3}+30.39\left(\frac{a}{t}\right)^{4}
\end{aligned}
$$

いま，溶込み不良をき裂と見なし，Fig. 12 の実験結 果加ら $\Delta \sigma_{e}=50 \mathrm{~N} / \mathrm{mm}^{2}, a=3 \mathrm{~mm}$ として $\Delta K_{\text {th }}$ を計算 すると, $6.3 \mathrm{MN} \cdot \mathrm{m}^{-3 / 2}\left(199 \mathrm{~N} \cdot \mathrm{mm}^{-3} / 2\right)$ の值が得られ る. この $\Delta K_{\text {th }}$ の侮を(7)式に代入すると， $\gamma_{p(c) e}$ は $0.063 \mathrm{~mm}$ 之計算される. 乙の值を(4) 式に代入し, 疼 学限度 $\Delta \sigma_{e}$ 之有效き裂深さ $a_{e}$ 之の関係を求好之,

Fig. 14 の笑線のようになる。 また，溶込み不良の哚さ $a$ が 2 4 mm の範围の溶接継手試験片の, 繰返し数 $10^{7}$

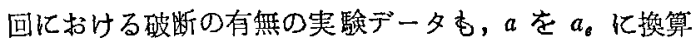
して図中にプロットした，実験した試験片の溶込み不良 の樑さ $a$ は正確に制御できなかったが, 2 3 $\mathrm{mm}$ と 3 $4 \mathrm{~mm}$ の溶込み不良の平均值がそれぞれ $2.5 \mathrm{~mm}$ と 3.5 $\mathrm{mm}$ であると仮定すると（4) 式と (6) 式から 6 。はそれ

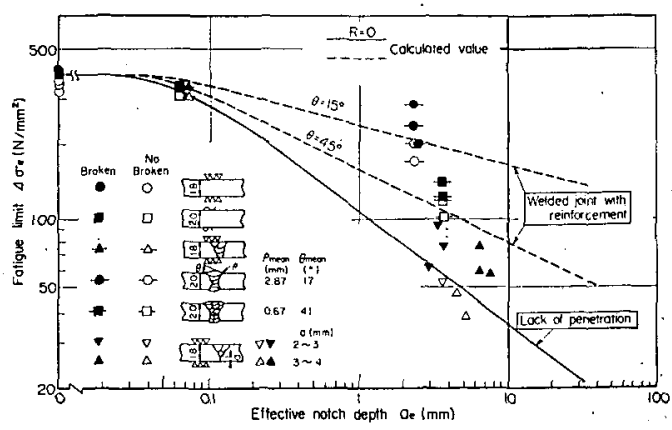

Fig. 14 Analysis of the fatigue limits of specimens with various weld discontinuities

ぞれ47.7と $58.3 \mathrm{~N} / \mathrm{mm}^{2}$ と計算され，Fig. 12 亿示した

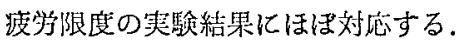

なお，黑皮付母材の疲学限度の值をての実線に当ては めれば、樑さが $0.07 \mathrm{~mm}$ 程度の表面きずを含むむの之 評価されよう。また，余盛りを削除した完全溶込み溶接 継手の疲労限度が平淔母材より若干低くなった理由とし ては，溶接残留灾力や材質的不連続に基つく応力集中効 果之考元られるが，黑皮付母材之同程度の応力符中効果 を持つものと評価されよう.

一方，余盛付突合甘溶接継手の疲労限度に対しては， 溶接止端部の応力份布はくさび形切欠きに近く，余盛り を先端半径が 0 のくさび形切久きと見なした解析が有効 であると報告されている14).また，Fig.15 に示すよう

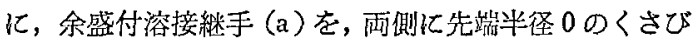
形の圳欠きを有する試験片（b）㯰き換えて考えると， 切矢底近傍の忘力 $\sigma$ は，くさびが浅い埸合次式で表さ れる ${ }^{14)}$.

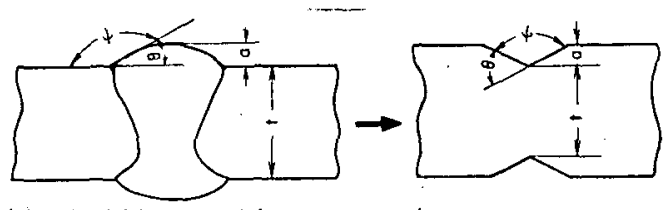

(o) Welded joint with reinforcement

(b) V-notched specimen

Fig. 15 Conversion of profile for reinforcement

$$
\sigma=\sigma_{0}\left\{\frac{\left(a_{\mathrm{e}}+\gamma\right)^{2}}{2 a_{a}+\gamma^{2}}\right\}^{m}
$$

ことで $\gamma$ は切欠き底加らの距嚁, $\mathrm{m}$ はくさび形切久 きの開き角 $\left.\psi r=180^{\circ}-\theta\right)$ の関数で, 宇佐美らの弾性応

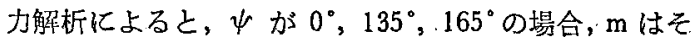
れぞれ $0.5 ， 0.33 ， 0.14$ となる15)。 $a_{e}$ はき裂の場合之同 様化（b）式加ら計算された無限板におりる有效切欠深 さである.

(9) 式にこれら m の値を代入し， $\gamma$ が渡労限度におけ 
る $\gamma_{D(c) e}$ に等しいとおいて $\sigma / \sigma_{0}$ を矿算した。そして，

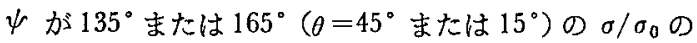
值亡 $\psi$ が $0^{\circ}$ における $\sigma / \sigma_{0}$ の佔の比を計算し，(4) 式 の $\Delta \sigma_{e}$ にこの值在乘じて $\Delta \sigma_{e}$ と $a_{e}$ との䦧の関係を求 めた、この計算結果を Fig. 14 の破線で示し, NRIM デ ターシートの余盛付溶接継手の奏験絬果と比較した。契 際の余盛付溶接継手の場合には，止端部の形状，先端半 径のばらつき，あるいは溶接残留応力や材質不連続に甚 つく応力集中効果などあ合わせて考慮に入れ検討されな ければならないが，奏用的に止端部をくさび形划欠きと 見なして評佂することができると思われる。

\section{5. 結}

言

アーク溶接継手の信頼性の確保のための基礎資料とし て得られた結果を要約すると次のと扔りである。

1) GMA 溶接において，ワイヤ溶滴移行形態がピッ ト及びブローホールの生成に大きく影響を及ぼし，スト リーミング移行及び短絡移行ではてれらの欠陷がはとん ど形成しない。

2）定電圧特性の電源を用い GMA 溶接で開先内を 母材端面まで突合せ浚接する場合，浴込みに及ぽすア一 クブローの影響は母材端面から約 $7.5 \mathrm{~cm}$ の籊圈内であ る.

3）溶込み不良などの寸法を超音波探賃試験法で定畐 的に測定するため, 球面振檕子を使用する点集束斜伯探 触子を設計試作し適用した。片側溶揬による溶込み不良 の埸合，探蚛子を溶込み不良の反対側に設置して测るA 法では，超音波ビームが浴接金属中を通過するので，そ の途中やルート部にブローホールなどがあると溶込み不 良の先端位置が正確に求められなくなる場合がある。一 方，探触子を溶込み不良侧に設犆して测るB法では，乙 のような問題がなく一般に適していると半断されるが， 片側溶込み不良の寸法が $2.5 \mathrm{~mm}$ 以下になると测定が 不可能となる。

4）突合せ溶接継手のルート面が機械仕上げで仕上げ 面の凹凹が溶接線方向に茾ふ場合には，上記 $\mathrm{A}$ 法です $\mathrm{B}$ 法であ溶込み不良の寸法を小さく見詥まることがある。 しかし，ルート面がガス切断のままの場合は問題なく， 㭘出精度は $\pm 0.5 \mathrm{~mm}$ 程度と推定される。

5）画側溶接による溶込み不良については，溶按継手 のルート面を平滑に機械仕上げを行い，溶接時の収維に よってルート面加強く密着される場合には，溶迄み不良 の検出が困難になる場合がある，したがって，内部溶込 み不良の検出には，ルート間隔がある程度以上存在する ことが必要である。

6) SM $50 \mathrm{~B}$ 䤾板 $(20 \mathrm{~mm}$ 3) のガスメタルアーク
(GMA）溶接による片側溶込み不良が疲学試験結果に及 ぼす影㗽につき，母材の表面状態，溶接継手の余盛りの 有然及び完全溶入みの場合と比较して検討した，その結 果, 媣さ 2 4 mm 程度の溶込み不良を含み，余盛りを 削除して表而砸削仩上げを行った溶接継手の疲労強度は 母材及び完全溶入みで余盛削除仕上げの溶接継手のそれ に比べて著しく低下した。

7）表面研削仕上げを行った母材と黑皮付きの母材の 疲労強度は近似していたが，表面研削仕上げを行った母 材の疲学強或の方がわずかに高かった，完全溶込みで余 盛りを削除し表面研削任上げを行った溶接継手の瘦労強 戋は，黒皮付きの母材のそれとほぼ同じ值を示した。し たがって，溶接による材質不連続が败労强度に及ぼす影

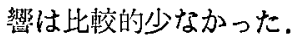

8）黒皮のままの余盛付被覆アーク（MAC）及び G MA 溶接継手の疲労強度は，母材のそれと溶込み不良を 含む溶接継手のそれの中間の值を示し，母材の㾉労強度 に比べてかなり低下した。

9）上記 (6)，(7)，(8) の実験結果について非線班破壊 力学的榆討を行い, 有效切欠深さと疲労限度との関係を 求めた，黑皮付母材の疲労限度は， $0.07 \mathrm{~mm}$ 程度の表 面きずを含むものに対応するすのと評価される。また， 余盛りを削除した完全溶込み溶接継手の溶接残留応力や 材質不連続に基つく応力策中効果は，黒皮付母材と同程 庋と評価される。さらに，余盛付溶接継手の疲労限度 は，止端部をくさび非切久きと見なしてほぼ評価するこ とができるようである。

\section{参文 献}

1）学田，大野，和田；フークおよびレビテーション溶解における溶鉄 扰上び溶触鉄命金中への窒菜溶解量について，本誌，38-4 (1969), 390-406

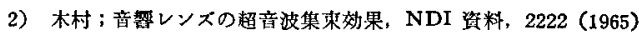

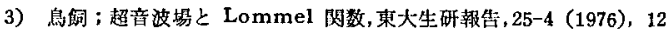

4) I.N. Ermolov; Use of Amplitude-Distance-Diameter Diagrams when Inspection with Inclined Probes, Defectoskopiya, 6-6 (1970), 41

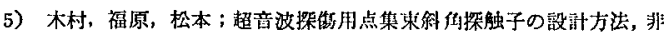
破垻梌查，31-1 (1982)，2

6）松本，木村，禎原；点集束斜折探触子の性能，NDI 資料 2669 (1978)

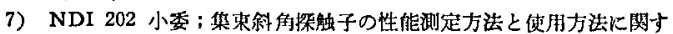
る指針，非破壤梌查，30-1 (1981)，30

8）日本溶接劦会；J1S Z3103「フーク溶接継手の片振り引㖘波九武監 方法 (改正案)」(昭和56年 3 月)

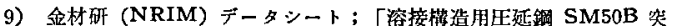
合せ溶接継手の坡れデータシート」, No. 5 (1978)

10）金材矿（NRIM）データシート；「溶接構造用压延鋼 SM50B 笑 合せ溶接艓手の㭚れデーターシートー溶接法の奻果」, No. 27 (1981)

11) M. Inagaki, M. Nihei, M. Kamakura, E. Sasaki and M. Kanao; Effects of Specimen Configuration and Test Frequency on Fatigue Strength, IIW Doc. XIII-994-81

12) S. Usami and S. Shida ; Elastic-Plastic Analysis of the 
Fatigue Limit for a Material with Small Flaws, Fatigue of Engineering Materials and Structures, Pergamon Press, Oxford, 1.4 (1979), 471-481

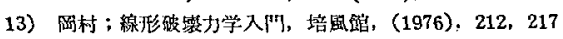

14）宇佐美，志由；〈さび形切欠きを有する部材の菠多限度，機械学会

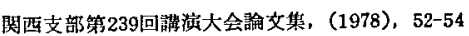

15) S. Usami, H. Kimoto and S. Kusumoto; Cyclic Strain and Fatigue Strength at the Toes of Heavy Welded Joint, Trans. JWS 9-2 (1978), 118-127

\title{
308 系溶接金属の高温特性に及ぼす溶接法の影響*
}

\author{
財前 孝**, 青木 司郎**, 鈴木 克已 ${ }^{* *}$, 橋本 勝邦** \\ Effects of Welding Methods on the High Temperature Properties \\ for the 308 Type Stainless Steel Weld Metals*
}

\author{
by Takashi Zaizen**, Shiro Aoki**, Katsumi Suzuki**, and Katsukuni Hashimoto**
}

\begin{abstract}
The effects of the welding methods, heat input and heat cycle on the mechanical properties at elevated temperature for the 308 type stainless steel weld metals rae investigated and the following results are obtained.

1) Creep rupture strength for the TIG arc weld metals is large about $2 \mathrm{~kg} / \mathrm{mm}^{2}$ compared with that for the submerged arc weld metals, and creep rupture elongation for the submerged arc weld metals is large compared with that for the TIG arc weld metals.

2) The oxygen contents of the submerged arc weld metals are more than ten times as much as those for the TIG arc weld metals. The oxygen in the weld metals forms the inclusion.

3) The inclusions in the submerged arc weld metals are from about 0.2 to $0.4 \mu$ in diameter, and are distributed at a mean interval of about $4 \mu$ in length. These inclusions decrease the both strengthes and increase the creep rupture elongation.

4) The hardness and the tensile rupture elongation for the lower heat input submerged arc weld metal are high compared with those for the higher heat input submerged arc weld metal.

5) Structures of solidification, dendrite, $\delta$ ferrite network for the low heat input submerged arc weld metal are fine compared with those for the high heat input submerged arc weld metal.

It is supposed that these fine structures increase the hardness and rupture elongations at tensile test. 6) As the followed thermal cycles increase the room temperature hardness for preceded weld metals, these thermal cycles have no effects on the tensile strength at elevated temperature and creep rupture strength of the preceded weld metals. These results are caused by the disappearance of the difference in the structures between the followed and the preceded weld metals during tests at the elevated temperature.
\end{abstract}

\section{1. 緒言}

308 K V $0.1 \%$ 添加した $308 \mathrm{~V}$ オーステナイトス テンレス罁は绶れた高温特性をむっている3.2). しかし ながら TIG 溶接㭁よびサブマージアーク (以下 SAW) 溶接などによる溶接金属は少量の金属を極めて短時間で 溶解・凝固させたあのである，したがって十分管理され たいくつかの製造工程を経て製品化された圧延鋼材に比

*原稿受付 昭和56年11月13日（昭和53年度春季全国大会にて発表）

**正具 新日本製鉄 (株) 製品技術研究所 Member, Product Research \& Development Labortories Nippon Steel Corp.
べると組織は小さな凝固組織となり，偏析の㑯向が強 く, 非平衡な空格子点が多く, 熱的に不安定で再加熱に よる組織変化が起こり易い.

また SAW 溶接の場合にはフラックスの影響で酸化物 介在物が生成されてのため TIG 材より酸装量が多くな る.さらに多層盛溶接金属において先行ビードは後行 ビードによる熱サイクルを多く受けるので，先行・後行 ビード間では組織が異なる，てのように溶接金属は通常 の鋼材には存在し難い特殊の因子が存在する.

一方鋼材の機械的性質は組織之強いかかわりがある. 高温引張やクリープ試験などの高温試験においては試験 